cereals was 81.6 million tons, the average output in 1927,1928 , and 1929 fell to 72.9 million tons, or a decrease of 10.7 per cent. This, however, was increased in 1930, under collective farming, to 87.4 million tons; but the hopes for 1931 of 97.9 million tons fell short by as much as 21.5 million, which, with an annual growth of population of $2 \cdot 36$ per cent, has meant a cessation of export. The shortage would appear to have been largely due to vain attempts to increase too rapidily the area under cereals, which led to badly propared soil, thin sowing, and delayed harvests. Less favourable weather was another cause. Novertheless, the sown area of cereal and other crops has been increased during the last yoar by more than seven per cent. An analysis of the output of large scale industry shows an increase in the last year of 2I.7 per cent, against the anticipated $44 \cdot 3$ per cent. At the same time, there are other negative results which are fully analysed in this report, such as the decrease in the productivity of labour, and the increase in cost of production and in prices.

\section{Antirabic Treatment in India}

That dread disease hydrophobia, caused by the bite of rabid animals, is of considerable importance in India, and 456 deaths were attributed to it in 1930 in the Madras Presidency. The report for 1930 of the Director, Major Iyengar, of the Pasteur Institute of Southern India, Coonoor, records that $54 \mathrm{I}$ patients were treated at the Institute, with 5 deaths, a mortality rato of 0.92 per cent. In addition, 4747 cases were treated at other centres in the Madras Presidency, with $\check{5}$ deaths. Semple's carbolised sheep vaccine was used throughout, the virus being in its 1Ij4th passage at the end of the year. Animals to the number of 229 , including one elephant, were also treated, with no death. Bites treated were inflicted by eleven species of animals, including man, panther, leopard, jackal, and fox.

\section{Investigation of the Atmosphere in the U.S.S.R.}

A scientific institute has recently been established in Moscow to carry on research on the circumstances of formation of eloud, fog and rainfall. The institute has branches in Leningrad, Odessa, Saratov, Teshkent, and Askhabad. The Leningrad branch of the institute is installing apparatus for investigating the effect on the atmosphere of high-tension currents, X-ray, ultraviolet rays and radioactive raciations. It is hoped to test the apparatus next simmer in experiments to be carried out in the drought regions of the U.S.S.R.

\section{Announcements}

AT a congregation held at Cambridge on June 11, the honorary degree of Sc.D. was conferred on Sir William Bragg, director of the Royal Institution.

Dr. Hentry S. Washingtos, the distinguished petrologist of the Geophysical Laboratory of the Carnegie Institution of Washington, has been elected an honorary member of the Mineralogical Society.

Prof. H. E. Armstrong will deliver the next Huxley Memorial Lecture at the Imperial College of

$$
\text { No. 3268, VoL. 129] }
$$

Science and Technology on May 4, 1933. Prof. Armstrong will speak on Huxley's educational creed and its outcome.

THE following committee has been appointed to inquire into the sterilisation of mental defectives : $\mathrm{Mr}$. L. G. Brock (chairman), Dr. Wilfrod Trotter, Dr. R. A. Fisher, Dr. A. F. Tredgold, Miss Ruth Darwin, Dr. E. W. Adams, Dr. R. H. Crowley, Dr. E. O. Lewis, with Mr. F. Chanter, of the Board of Control, as secretary. The terms of reference are: "To examine and report on the information already available regarding the hereditary transmission and other causes of montal disorder and deficiency ; to consider the value of steril. isation as a preventive measure, having regard to its physical, psychological, and social effects, and to the experience of legislation in other countries permitting it; and to suggest what further inquiries might usefully be undertaken in this connexion".

Thw reports of the destruction of a gaol at Mymensingh, in Bengal, on May 9 last, by a tornado, were probably ineorrect in attributing the damage to a tornado, for the 'nor'westers' are quite capable of doing all the damage described on this occasion and are particularly frequont in May. These squalls, associated with early summer thunderstorms in Northern India, can be very violent.

A swW catalogue (No. 549) of second-hand books and journals has just reached us from Francis Edwards, Ltd., 83 High Street, Marylebone, W.1. It comprises nearly 1700 works-many rare-dealing with folklore and anthropology.

Applications are invited for the following appoint. ments, on or bofore the dates mentioned :-A lecturer in the Chemistry Department of the Heriot-Watt College, Edinburgh-The Principal, Heriot-Watt Colloge, Edinburgh (June 20). A principal of the Walsall Technical College-The Director of Education, Education Offices, Council House, Walsall (June 25). A principal of the Chelmsford School of Art and Technology--The Director of Education, County Offices, Chelmsford (June 25). A lecturer in zoology (botany subsidiary) at the Chelsea Polytechnic-The Principal, Chelsea Polytechnic, Manresa Road, S.W.3 (June 30). A lecturer in the department of botany in the University of Durham (Durham Division)The Head of the Department of Science, Lniversity of Durham, South Road, Durham (July 1). An F. W. Bennett lecturer in physics at University Colloge, Leicester-The Registrar, University College, Leicester (July 5). A graduate assistant master to teach mathematics, with elementary science as subsidiary subject, in the Halifax Junior Technical Sehool - The Principal, Municipal Technical College, Halifax. An assistant master for the teaching of painter's and decorator's work at the Huddersfield Technical College -The Director of Education, Education Offices, Peel Street, Huddersfield. A chief instructor in agricultural subjects at the Army Vocational Training Centre, Chisledon, Wiltshire-The Commandant, Army Vocational Training Centre, Chisledon, Wiltshire. 